\title{
POLITIK HUKUM PEMBENTUKAN LEGISLASI BIDANG EKONOMI SYARIAH DI INDONESIA
}

\author{
${ }^{1}$ Ichwan Ahnaz Alamudi dan ${ }^{2}$ Ahmadi Hasan \\ ${ }^{1}$ Kolaborasi Penelitian Mahasiswa dan ${ }^{2}$ Dosen \\ Pascasarjana Universitas Islam Negeri Antasari Banjarmasin \\ Jalan Ahmad Yani KM 4,5 Banjarmasin-Kalimantan Selatan
}

\begin{tabular}{l} 
Article Info \\
\hline Article history: \\
Received Jan $28^{\text {th }}, 2021$ \\
Revised Mar $24^{\text {th }}, 2021$ \\
Accepted June $01^{\text {th }}, 2021$ \\
\end{tabular}

\section{Keyword:}

Politik;

Legislasi;

Ekonomi;

Syariah;

Indonesia

\begin{abstract}
This study will disclose that the construction of legal legislates in the Islamic area is influenced by a sharia-based law polit. This is because community elements are Muslim majority. This study's method is more likely to be a legal-normative study with a legal-political approach. The government's function as a legislator in the establishment of Sharia economic law, according to this study, cannot be separated from the participation of users, the majority of whom are Muslims.
\end{abstract}

\begin{abstract}
Abstrak: Penelitian ini akan mengungkap bahwa pembentukan legislasi hukum bidang Syariah di Indonesia dipengaruhi oleh politk hukum berbasis Syariah. Hal ini dikarenakan factor masyarakat yang mayoritas muslim. Metode yang digunakan dalam penelitian ini lebih cenderung pada kajian yuridis-normatif dengan pendekatan politik hukum.Penelitian ini menemukan bahwa pemerintah sebagai legislator dalam pembentukan hukum ekonmi Syariah tidak terlepas dari peranan pengguna, yang mayoritasnya beragama Islam.
\end{abstract}

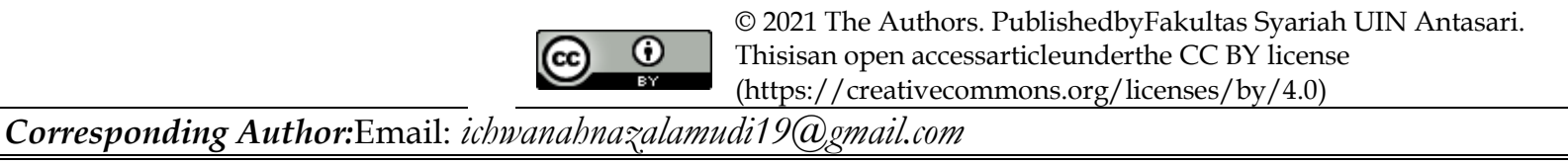

\section{Pendahuluan}

Secara yuridis penerapan hukum ekonomi syariah di Indonesia memiliki dasar hukum yang sangat kuat ketentuan pasal 29 ayat (1) dengan secara tegas menyatakan bahwa Negara bersadar atas Ketuhanan Yang Maha Esa, pada dasarnya mengandung tiga makna diantaranya; Negara tidak boleh membuat peraturan perundang-undangan atau melakukan kebijakan-kebijakan yang bertentangan dengan dasar keimanan kepada Tuhan Yang Maha Esa, Negara berkewajiban membuat peraturan perundangundangan atau melakukan kebijakan-kebijakan bagi pelaksanaan wujud rasa keimanan kepada Tuhan 
Yang Maha Esa dari segolongan pemeluk agama yang memerlukannya, Negara berkewajiban membuat peraturan perundang-undangan yang melarang siapapun melakukan pelecehan terhadap ajaran agama.

Dalam pasal 29 ayat (2) UUD 1945 disebutkan bahwa Negara menjamin kemerdekaan tiap-tiap penduduk untuk memeluk agamanya masing-masing dan untuk beribadat menurut agama dan kepercayaannya itu. Kata menjamin sebagaimana termaktub dalam ayat 2 bersifat imperatif, negara berkewajiban secara aktiv melakukan upaya-upaya agar tiap-tiap penduduk dapat memeluk agama dan beribadat menurut agama dan kepercayaannya itu. Sebenarnya apabila merujuk pada ketentuan pasal itu seluruh syariat Islam khususnya yang menyangkut bidang hukum muamalat pada dasarnya dapat dijalankan secara sah dan formal oleh kaum muslimin, baik dalam cara langsung maupun tidak langsung dengan jalan mengadopsi sistem hukum positif nasional.

Lahirnya produk hukum bidang ekonomi syariah dipahami sebagai bentuk apresiasi dan akomodasi pemerintah terhadap hukum yang hidup di masyarakat (living law). Selain itu untuk membangun kepastian hukum dibidang ekonomi syariah prolegnas perlu agar kiranya mendukung legislasi nasional ekonomi syariah dengan mengagendakan dan memberikan prioritas perundangundangan yang berkaitan dengan ekonomi syariah.

\section{Metode Penulisan}

Penelitian ini menggunakan pendekatan yuridis-normatif, yaitu pendekatan yang didasarkan pada peraturan perundang-undangan, teori-teori, dan konsep-konsep yang berhubungan dengan cakupan hukum mengenai regulasi-regulasi pada bidang ekonomi syariah dengan mencoba menggunakan metode politik hukum. Sumber data dalam penelitian ini adalah data kepustakaan, sedangkan jenis data yang dibutuhkan dalam penelitian ini adalah data sekunder. Data sekunder merupakan data yang diperoleh dari studi kepustakaan terhadap bahanbahan hukum atau referensi yang berkaitan dengan permasalahan penelitian. Studi kepustakaan dilakukan terhadap bahan- bahan hukum yang berkaitan dengan permasalahan penelitian yaitu tentang politik hukum pembentukan legislasi bidang ekonomi syariah.

\section{Pembahasan}

\section{Diskursus Politik Hukum}

Politik hukum dalam terjemahan bahasa Belanda "reht politik" yang memiliki arti kebijakan (policy) sehingga dapat diartikan sebagai kebijakan hukum. Klan menjelaskan kebijakan adalah hasil dari suatu tindakan melalui proses secara teratur dan sistematis, dengan memakai alat yang cocok, dengan tujuan sebagai tujuan politik yang dilaksanakan langkah demi 
langkah. ${ }^{1}$ Namun ada perspektif lain mengatakan bahwa politik hukum itu mengndung dua istilah arti yaitu "politik dan hukum". Politik dikatakan sebagai tingkah laku kolektif untuk mencapai tujuan secara kolektif, sehingga dapat dimaknai bahwa politik merupakan suatu rencana yang dijalankan untuk mencapai suatu rencana yang terorganisir dengan usaha menghasilkan, mempertahankan dan mengubah suattu sistem dalam tatanan masyarakat.

Kemudian mengenai konteks ini Prof. Mahfud MD mendeskripsikan tentang politik hukum. Beliau menerangkan bahwa "politik hukum adalah legal policy atau disebut dengan garis kebijakan resmi tentang hukum yang akan diberlakukan baik dalam perihal pembuatan hukum baru atau penggantian hukum lama dalam proses mencapai tujuan negara". ${ }^{2}$ maka itu dapat diresapi bahwa politik hukum merupakan alternatif dari suatu hukum yang akan diberlakukan dan alternatif dari hukum yang akan dicabut atau tidak diberlakukan dengan dasar semua itu dalam rangka untuk mencapai tujuan negara sebagaimana jelas termaktub dalam Pembukaan Undang-Undang Dasar Negara Republik Indonesia Tahun 1945.

Berangkat dari studi politik hukum Mahfud MD berbicara lebih awal mengenai tentang pemisahan sebelum menjadi satu antara studi politik dan studi hukum, dalam asumsinya terdapat tiga hal yang menjadi dasar, yaitu (1) hukum determinan menentukan atas politik, yang memiliki interpretasi bahwa hukum seharusnya menjadi suatu kendali atas aktivitas politik. (2) politik determinan atas hukum, memiliki makna dalam hal nyata, baik pada konteks produk hukum atau dalam sisi penegakkannya, sangat dipengaruhi atas politik. (3) politik dan hukum menjadi hubungan yang saling bergantung, seperti adagium "akan anarkis apabila politik tanpa hukum karena melahirkan tindakan kesewenang-wenangan, akan tetapi apabila hukum tanpa politik akan menjadi lumpuh.",3

Dalam tataran empiris, politik hukum sejatinya sudah digunakan dalam memahami relevansi antara hukum dan politik dalam kajian Mahfud MD, beliau dalam hal ini melihat suatu fenomena hukum melahirkan sebuah pendekatan baru. Hukum dalam sisi yuridis-sosio politis, yang menjadikan suatu sistem politik memberi pengaruh terhadap rumusan dan pelaksanaan hukum, sehingga dalam penelitiannya terdapat suatu proses pada konfigurasi politik pemerintahan tertentu akan berpengaruh pada produk hukum yang dilahirkan. Maka muncul

${ }^{1}$ Imam Syaukani dan A. Ahsin Thohari, Dasar-Dasar Politik hukum, Cet Ke-8, (Jakarta: Rajawali Press 2012), h. 22. Lihat juga dalam Ahmadi Hasan, Sejarah legislasi hukum ekonomi syariah di Indonesia (LKiS, 2017).

${ }^{2}$ Moh. Mahfud MD, Politik Hukum di Indonesia, Cet Ke-3, (Jakarta: Rajawali Press, 2010), h.1.

${ }^{3}$ M. Rifqinizamy Karsayuda, Jurnal Syariah dan Hukum:de Jure, Politik Hukum Nasional Legislasi hukum Ekonomi Syariah, Volume 7 No. 1 (Juni-2015), h. 41. 
sebuah teori politik hukum bahwasanya konfigurasi politik pada negara yang sistemnya demokrastis, karekteristik produk hukum akan bersifat responsif dan populistik, berbeda dengan konfigurasi politik pada negara dengan sistem otoritarian, produk hukum yang dilahirkan akan bersifat ortodoks dan konservatif serta elitis. ${ }^{4}$

Politik hukum diartikan sebagai suatu kebijakan untuk melaksanakan tujuan negara khususnya dalam bidang hukum pada hukum yang akan berjalan, sedang berjalan dan telah berlaku yang dimbil melalui nilai-nilai dalam masyarakat untuk mencapai tujuan negara sebagaimana terdapat dalam UUD NRI 1945 alinea ke-4, yang memberi ketegasan dalam citacita yang harus dicapai oleh bangsa Indonesia melalui organisasi Negara Kesatuan Republik Indonesia. dalam rangka mewujudkan tujuan negara maka seyogyanya harus terlaksana pembangunan hukum nasional, maka dengan terwujudnya pembangunan hukum nasional menjadi suatu langkah mudah untuk bangsa Indonesia dalam mencapai tujuan negara.

Tidak heran dalam dewasa ini jika membicarakan kata politik dan hukum apabila disandingkan, maka dianntaranya akan ada yang tersisihkan. Ketika dalam konteks ini fokus kedalam politik maka hukumlah yang akan tersisihkan. Tetapi jika fokus dalam kajian hukum maka politik yang tersisihkan pula. Namun dalam hal ini menjadi realitas banyak pengamat bahwa politik yang akan mempengaruhi hukum. Politik dengan tujuan menngumpulkan kekuatan massa untuk mencapai sebuah tujuan, sedangkan hukum menjadi suatu objek yang harus dipatuhi masyarakat berisi aturan-aturan serta hak dan kewajiban yang terkandung didalamnya.

Selanjutnya bagimana afiliasi antara subsistem hukum dengan subsistem politik. Salah satu aspek yang menarik relevansi antar keduanya dipengaruhi oleh adanya suatu pembeda dalam konsentrasi energi, subsistem politik dalam ini ternyata mempunyai konsentrasi stamina yang lebih besar dibandingkan dengan subsistem hukum. Apabila keduanya disandingkan, maka hukum berada dalam posisi yang lemah. ${ }^{5}$ Hal itu dikatakan sebagai hubungan yang mengkondisikan, sementara yang diketahui bahwa politik suatu kondisi bagi dijalankannya suatu lahirnya produk-produk hukum.

Benar adanya jika dikatakan tentang suatu hukum tidak murni, karena dalam konteks ini politik seringkali menjadi intervensi atas dibuatnya hukum atau implementasi hukum sehingga muncul dalam suatu diskursus bahwa subsistem mana antara hukum dan politik yang lebih suprematif. Mengenai hukum dalam negara-negara berkembang tentu dirasa perlu berbicara

${ }^{4}$ Moh. Mahfud MD, Politik Hukum..., h. 22.

${ }^{5}$ Satjipto Rahardjo, Membangun dan Merombak Hukum Indonesia Sebuah Pendekatan Lintas Disiplin, (Yogyakarta: Genta Publishing, 2009), h. 130. 
dalam konteks hubungan antara politik dan hukum, perhatian Nonet dan Selznick pertama kali tertarik pada hukum dan penindasan. Setiap hukum memiliki potensi untuk melakukan praktik penindasan, hukum dan kekuasaan memiliki hubungan sentral yang menyebabkan ada kewenangan untuk menuntut warga negara agar mematuhi kekuasaan yang bertahta.

Politik dalam hal ini memberi atmosfer begitu besar terhadap hukum sehingga sering kali untuk mencapai cita-cita hukum banyak terjadi hambatan. Hukum diselimuti oleh politik dan kedudukan hukum menjadi lemah apabila disandingkan dengan sistem politik yang ada. Politik hukum sederhana dirumuskan sebagai dasar kebijakan yang akan dilaksanakan dalam lingkup nasional oleh pemerintah. Asumsi dasar tentang pernyataan bahwa hukum adalah produk politik maka menjadi jawaban itu seyogyanya adalah hukum dinilai sebagai variabel yang terpengaruh, sedangkan politik dinilai sebagai variabel yang berpengaruh.

Dalam satu contoh pada sidang perlemen bersama pemerintah untuk melakukan pembutan undang-undang sebagai salah satu produk hukum pada konsep sebenarnya hal itu merupakan aktivitas konstelasi politik agar kepentingan semua terakomodasi didalam keputusan politik sehingga menjadi undang-undang dan UU itu lahir melalui proses keputusan bersama dan dilihat sebagai produk aktivitas konstelasi politik. ${ }^{6}$ Sehubung dengan kuatnya energi politik, maka hukum adalah kekuasaan, sebagian pengikut aliran positivism hukum mengatakan bahwa kepatuhan hukum tidak lain adalah tunduknya orang yang lebih lemah pada kehendak yang lebih kuat, sehingga hukum dikatakan hanya untuk hak orang yang kuat. ${ }^{7}$

Berbicara tentang politik hukum dalam nasional bahwa sejatinya untuk mewujudkan citacita ideal negara Republik Indonesia memiliki aspek berikut, diantaranya; sebagai suatu alat yang dipakai oleh pemerintah dalam sarana mencapai suatu sistem hukum yang dikehendaki, hukum nasional akan diwujudkan melalui cita-cita bangsa Indonesia yang besar. Dalam konteks ini tentu yang digunakan sebagai pijakan dalam mewujudkan hukum nasional adalah peraturan perundang-undang yang berdasarkan pada sistem ideologi dan konstitusi negara, yaitu Pancasila dan UUD NRI 1945. Perlu ditandai dalam hal ini hukum nasional tidak bisa terlepas begitu saja dalam kontek sejarah, diketahiui dalam konteks sejarah ini bangsa Indonesia pada mulanya masih belum memiliki hukum sehingga hukum yang ada saat awal dulu merupakan hasil adopsi dari hukum kolonial Belanda, kemudian atasa dasar pertimbangan politik bangsa hukum tersebut dinasionalisasi seperti pergantingan dalam kitab undang-undang. Dalam pendekatan yang

\footnotetext{
${ }^{6}$ Moh. Mahfud MD, Politik Hukum..., h. 10

${ }^{7}$ Ibid, h. 13 .
} 
dilakukan tersebut bermaksud untuk mengisi serta menghindarkan dari terjadinya kekosongan hukum.

Terkait uraian diatas tentang kajian politik hukum bagiamana dipahami bahwa politik mempengaruhi hukum dalamhal menilik persoalan konfigurasi kekuatan yang ada dibelakang pembuatan dan penegakkan hukum. Dan dalam hal ini menjadi pertimbangan baik buruknya hukum serta cocok tidaknya pemberlakuan hukum dalam sosial kemasyarakatan, menyebut hal itu mayorritas para ahli memberi argumentasi bahwa politik hukum ini istilahnya suatu proses interkasi antar para elit politik sebagai pemangku kebijakan. Dalam satu misalkan mayoritas para elit politik ini didominasi oleh para tokoh Islam maka bisa saja asumsi itu muncul kekuatan Islam mempunyai daya tawar yang tinggi dalam interaksi politik, sehingga pengembangan hukum Islam pun memiliki peluang yang begitu besar. ${ }^{8}$

Dari berbagai ragam definisi itu tadi seyogyanya politik memberikan dua isyarat utama yang berlayar secara dialektis, yaitu sebagai legal policy dan sebagai motor untuk memberi nilai serta kritisisasi atau alat pengendali. Dalam diskursus yang m,enjadi sebuah problematika apakah hukum yang dibuat sudah sesuai dengan pola pikir legal policy, sebagai legal policy tentu hukum memiliki standarisasi dalam menentukan arah tujuan negara yang ingin dicapai, dari sekian banyak produk hukum bisa diamati baik dalam peraturan perundang-undangan. Kemudian diskursus tentang politik hukum dikatakan sebagai alat pengendali memiliki interpretasi dalam taraf penerapan suatu produk hukum, agar tujuan berjalannya kebijakan hukum terjalankan sebagaimana fungsinya. ${ }^{9}$

Pembentukan peraturan perundangan-undangan yang ada merupakan bagian dari konsep politik hukum yang ada, semua berada didalam ruang konfigurasi bebas nilai, nilai-nilai berasal dari pendekatan sosial, budaya, politik, ekonomi, dan hukum. Respon terhadap hal itu bahwa semua saling berinteraksi satu sama serta mempengaruhi, sehingga konfigurasi yang ada saat ini tidak hanya berpatokan kepada satu konfigurasi. Dalam hal ini konfigurasi itu dalam pembentukan perundang-undangan yang ada menangkap tiga dasar klasifikasi hukum yang berlaku dimasyarakat, diantaranya: ${ }^{10}$

- Hukum atau Peraturan perundang-undangan sebagai pelayan kekuasaan yang represif.
h. 108
${ }^{9} \mathrm{Ibid}, 108$
${ }^{10}$ Ibid, 109

${ }^{8}$ Lukman Santoso, Jurnal Sosio-Religia, Politik Hukum Ekonomi Syariah, Volume 10 No. 2 (Mei-2012), 
- Hukum dan peraturan perundang-undangan sebagai institusi yang independent mampu membuat jinak dan melindungi integritas dirinya.

- Hukum dan peraturaqn perundang-undangan sebagai fasilitator berbagai tanggapan terhadap keperluan atas aspirasi sosial.

Hasil yang sama juga diperoleh oleh Benny K. Harman terhadap afiliasi linear antara konfigurasi politik dengan kekuasaan kehakiman. Menurutnya apabila dalam sebuah negara penerapan konfigurasi politik yang demokratis, karakter kekuasan kehakiman yang akan dihasilkan bersifat independent atau otonom, begitu juga berimplikasi balik bahwa apabila konfigurasi politik yang otoriter atau totaliter, akan menghasilokan konfigurasi yang tidak otonom dan tidak bebas. ${ }^{11}$ Bila diamati Mahfud MD ataupun Harman memakai suatu dasar yang sama, ada hubungan antara politik dan hukum. Walaupun penelitian mereka berdua dalam objek yang berbeda, Mahfud MD titik tekan berada pada konfigurasi politik dan karakteristik produk hukum sedangkan Harman konfigurasi politik dan karakteristik kekuasaan kehakiman. Sehingga hasil penelitiannya adalah konfigurasi politik sangat memberi pengarauh terhadap produk hukum dan kekuasaan kehakiman.

Problematika yang terjadi dalam dunia akademis konsep diatas apakah termasuk dalam penelitian hukum atau politik? Mahfud MD dalam bukunya secara jelas memberi penjelasan bahwa model yang dilakukan ini adalah model penelitian hukum bukan penelitian politik. Argumentasinya bahwa politik hukum merupakan bagian dari ilmu hukum bukan ilmu politik, ia menjelaskan ilmu hukum ibarat sebagai pohon, filsafat menjadi akarnya, politik bagian batangnya yang melahirkan cabang-cabang berupa berbagai bidang hukum, seperti hukum perdata, hukum pidana, hukum tata negara, hukum administrasi negara dan lain-lain.

\section{Produk Legislasi Ekonomi Syariah Dalam Tatanan Hukum Nasional}

Negara Kesatuan Republik Indonesia melalaui Undang-Undang Dasar sebagai konstitusi menyatakan bahwa Indonesia adalah negara hukum. Tentu sebelum amandemen dilakukan penjelasan terkait bahwa Indonesia adalah negara hukum ditemui yang menyatakan: "Indonesia ialah negara yang berdasarkan atas hukum (rechtsstaat)." "Negara Indonesia berdasarkan atas hukum tidak berdasarkan atas kekuasaan belaka. Setelah Undang-Undang Dasar Negara Republik Indonesia dilakukan amandemen, pernyataan bahwasanya bangsa Indonesia sebagai

${ }^{11}$ M. Rifqinizamy Karsayudha, Politik Hukum..., h. 42. 
negara hukum termaktub pada BAB I Pasal 1 ayat (3) yang menyatakan "Negara Indonesia adalah negara hukum."12

Berangkat dari hal itu kehadiran ekonomi syariah dalam tatanan hukum Indonesia dalam dewasa ini bukan sebagai tuntutan sejarah atau tuntutan atas penduduk Indonesia yang mayoritas beragama Islam. Akan tetapi semua itu dikarenakan kebutuhan masyarakat luas setelah diketahui bahwa begitu adil dan meratanya sistim ekonomi syariah dalam mengawal kesejahteraan rakyat sesuai dengan cita-cita bangsa, melihat kedudukan ekonomi syariah juga semakin kuat jika dilihat afiliasi dengan falsafah dan konstitusi negara. sederhananya sistem ekonomi syariah tidak sama sekali bertentangan dengan pancasila terutama dalam sila pertama "ketuhanan Yang Maha Esa", maupun dengan konstitusi negara yang berbunyi "dengan mewujudkan suatu keadilan sosial bagi seluruh rakyat Indonesia," semua itu ditegskn pul dalaam turunannya BAB XI Agama Pasal 29 ayat (1) dan (2), serta BAB XIV Pasal 33 yang mengatur perihal perekonomian nasional dan keejahteraan sosial Indonesia. ${ }^{13}$

Dalam konteks ini tentu tidak terlepas dari kajian politik hukum ekonomi syariah yang atas berlakunya hukum Islam di Indonesa, pada hakikat untuk mencapai suatu itu penuh dengan proses yang panjang dan mengalami dinamika hukum dari zaman penjajahan Belanda, kemerdekaan dan sampai pada reformasi saat ini. Sehingga ada beberapa teori atas berlakunya hukum Islam sebagai berikut:

- Teori Receptio in Complexu

Pendapat L.W Christian Van Den Berg memiliki penyataan bahwa hukum mengikuti agama yang dianutn seseorang, jika orang itu memeluk agama Islam maka hukum Islamlah yang berlaku baginya. Menurut Berg orang Islam Indonesia telah melalukan resepsi hukum Islam dalam keseluruhan dan sebagai satu kesatuan yang disebut dengan receptio in complexu. ${ }^{14}$

\section{- Teori Receptio}

Teori Receptio in Complexu mendapat bantahan dari Snouck Hurgronje, menurutnya adalah hukum yang berlaku bagi orang Islam adalah hukum adat. Hukum Islam akan berlaku jika sudah diterima oleh hukum adat, teori ini terkenal setelah disistematisasi dikembangkan oleh Cornelis Van Vollenhoven dan para pengikutnya. Teori ini dikatakan sangat mengerdilkan atas hukum.

12 Penjelasan UUD 1945 Setelah Amandemen yaitu Pasal 1 ayat 3;'Indonesia adalah negara yang berdasar

${ }^{13}$ Lihat Undang-Undang Dasar 1945 Pasal 29 dan Pasal 33.

${ }^{14}$ Mustafa Khamal Rokan, Politik Hukum Ekonomi Syariah di Indonesia, (2015), h.3. 
bahkan menghapuskan keberlakuaannya hukum Islam di Indonesia, pada saat teori ini berlaku politik hukum Islam benar-benar berada dalam kemunduran bahkan dalam jurang kehancuran. ${ }^{15}$

\section{- Teori Receptio Exit}

Muncul suatu pertentangan atas teori yang dikemukakan oleh Snouck Hurgronje para ahli hukum Islam mengatakan bahwa teori receptio merupakan teori iblis. Teori ini memiliki tujuan agar mematikan hukum Islam yang sudah diterima oleh masyarakat Indonesia, pemahaman terhadap inilah yang disebut teori receptio exit bahwa akan menghapuas atau keluar dari teori receptio. Berlakunya teori ini ketika dilakukan pengesahan terhadap UUD 1945 dan PPKI, keberlakuan hukum Islam akhirnya dimasukkan kedalam rumusan dasar negara Republik Indoensia yang dikenal dengan Piagam Jakarta sebelum dihapuas tujuh kata "dengan kewajiban menjalankan syariat Islam bagi pemeluk-pemeluknya."16

- Teori Eksistensi

Teori eksistensi adalah suatu teori yang menerangkan tentang adanya hukum Islam dalam hukum Nasional. Menurut teori ini letak eksistensi hukum Islam dan hukum Nasional ialah, hukum Islam berada dalam hukum nasional sebagai bagian integral darinya, kemandirian yang diakui dalam hukum nasional, hukum Islam sebagai penyaring bahan-bahan hukum nasional. ${ }^{17}$

Berangkat dari teori itu tentu dalam proses sejarahnya pun berpengaruh besar terhadap positifikasi hukum dibidang ekonomi syariah. Istilah ekonomi syariah dalam dewasa ini dkenal secaraa luas di Indonesia karena dikatakan sistem ekonomi ini sebagai sejarah baru dan alternatif bagi ekonomi barat, seperti ekonomi sosialisme dan kapitalisme. Hadirnya ekonomi syariah sebagai gagasan baru dalam mengakomodasi sistem ekonomi yang ada, karena dianggap ekonomi barat terdapat kelemahan mendasar. Ekonomi syariah tidak hanya untuk mempersiapkan indvidu-individu tetapi dalam hal ekonomi memudahkan model kerjasama yang berlandaskan syariah serta memberikan pendidikan moral yang tinggi dalam kehidupan. ${ }^{18}$

Sesungguhnya aktualisasi nilai-nilai ekonomi syariah menjadi signifikan terutama dalam hal mencari jalan keluar dari krisis multidimensional yang dialami bangsa Indonesia. pelembagaaan sisitem ekonomi syariah dalam operasioanlnya diharapkan menjadi suatu alternatif upaya dalam optimalisasi sumber daya ekonomi masyarakat tidak lain bagi umat

\footnotetext{
${ }^{15}$ Ibid, h. 4

${ }^{16}$ Ibid, h. 4

${ }^{17} \mathrm{Ibid}, \mathrm{h} .5$.

${ }^{18}$ Mul Irawan, Jurnal Media Hukum, Politik Hukum Ekonomi Syariah Dalam Perkembangan Lembaga Keuangan Syariah Di Indonesia, Volume 25 No 1 (Juni-2018), h.13.
} 
muslim yang pada waktu itu meragukan terhadap kehalalan sistem bunga dalam praktik perbankan konvensional, dengan sistem ekonomi syariah yang diharapkan sebagai payung bagi semua lembaga keuangan syariah dengan berbasis ajaran Islam pada akhirnya dapat menjadi pencerahan yang selama ini menjadi bentuk praktik ribawi. ${ }^{19}$

dalam hal ini bahwa hukum Islam menjadi sumber huukum nasional bersama dalam hukum barat dan hukum adat, akan tetapi bukan berarti harus menjadi hukum formal yang dengan sendirinya secara ekslusif, kecuali yang sifatnya untuk melayani bukan memberlakukan dengan imperatif terhadap yang sudah berlaku sebagai kesadaran dalam kehidupan sehari-hari. Hukum Islam dalam hal ini sudah lam mendapatkan tempat di Indonesia dalam konteks berlakunya baik secara normatif, sosiologis dan yuridis. Menurut Amin Summa urgensi dari berlakunya suatu hukum Islam di Indonesia adalah dengan alasan konstitusi dan alasan sejarah serta kebutuhan terhadap hukum Islam itu sendiri. ${ }^{20}$

Prinsip-prinsip ekonomi syariah adalah bagian dari ajaran moral Islam yang menjadi dasar dalam kegiatan ekonomi. Prinsip tersebut antara lain adalah: pertama: Tauhid, artinya bahwa aktivitas produksi dan konsumsi berpijak pada prinsip penghambaan kepada Allah SWT. Kedua: isti'mar dan istikhlaf, bahwa amanah kepada manusia untuk mengelola kehidupan didunia harus dapat dipertanggungjawabkan secara moral terhadap tuhan dan kemanusiaan. Ketiga: kemashlatan, aktivitas ekonomi dapat dilakukan sejauh mendatangkan manfaat serta menolak kerusakan terhadap manusia dan alam semesta. Keempat: kedilan, aktivitas ekonomi harus dilakukan dengan suatu kerangka mewujudkan keadiln sosial bagi seluruh lapisan masyarakat. Kelima:kesejahteraan dunia akhirat lahir dan bathin. ${ }^{21}$

Dari uraian diatas Indonesia dalam perencanaan serta pembangunan hukum yang dilakukan akan tetap memperhatikan kemajemukan tatanan hukum yang berlaku dengan upaya mencakup meningkatkan kesadaran hukum, kepastian hukum, perlindungan hukum, penegakkan hukum dan pelayanan hukum yang beresensi pada keadilan dan kebenaran dalam rangka

19 Illy Yanti, Jurnal: Al-Risalah, Formalisasi Hukum Ekonomi Islam Di Indonesia (Studi Tentang Pemberlakuan Hukum Ekonomi Islam Pasca Lahirnya UU No. 3 Tahun 2006), Volume 13 No 2 (Desember-2013), h. 7

${ }^{20}$ Muhammad Amin Suma, Himpunan Undang-Undang Perdata Islam dan Peraturan Pelaksana Lainnya Di Negara Hukum Indonesia, (Jakarta: Raja Grafindo Persada, 2004), h. 4.

${ }^{21}$ Fasiha, Ekonomi dan Bisnis Islam: Seri Konsep dan Aplikasi Ekonomi dan Bisnis Islam, (Jakarta: PT Raja Grafindo Persada, 2016), h. 445. 
penyelenggaraan negara yang semakin tertib dan teratur. ${ }^{22}$ pembangunan pada bidang ekonomi syariah dinilai ekonomi syariah memberi sebuah kontribusi yang banyak pada saat Indonesia mengalami krisis moneter dengan hal ini menjadi perhatian khusus untuk memberikan kedudukan hukum yang terbaik dalam sisi normatifnya.

Dalam upaya positifikasi hukum Islam kedalam hukum nasional merupakan bagian dari politik hukum yang mengikutsertakan para pemangku kebijakan yang memiliki otoritas untuk merumuskan hukum baik dengan jalan proses inisiatif pemerintah membuat produk hukum atau undang-undang yang disahkan oleh Dewan Perwakilan Rakyat. Dalam hubungannya dengan perkembangan regulasi hukum bidang ekonomi syariah dengan ini disampaikan beberapa hasil produk legislasi yang ada, diantaranya:

- Diundangkannya Undang-Undang Nomor 19 Tahun 2008 tentang Surat Berharga Syariah Negara (SBSN) yang disahkan pada 7 mei 2008. Lahirnya produk hukum ini dengan tujuanmembiayai Anggaran Pendapatan dan Belanja Negara yang selalu defisit, termasuk juga untuk pembiayaan proyek. Pemerintah memiliki alasan mendasar dikeluarkannya produk hukum ini, undang-undang ini akan mendukung perkembangan sukuk dalam rangka nantinya sebagai alternatif sumber biayaan negara. ${ }^{23}$

- Diundangkannya Undang-Undang Nomor 21 Tahun 2008 tentang Perbankan Syariah, produk hukum ini bertujuan untuk mencapai tujuan pembangunan nasional Indonesia berupa terciptanya masyarakat adil makmur berdasarkan demokrasi ekonomi, pengembangan sistem ekonomi yangberlandaskan nilai keadilan, kebersamaan, pemerataan, dan kemanfaatan sesuai dengan prinsip-prinsip syariah. Selanjutnya kebutuhan masyarakat akan jasa-jasa perbankan syariah yang semakin meningkat dan regulasi yang diatur melalui Undang-Undang Nomor 7 Tahun 1992 sebagaimana mengalami perubahan dalam Undang-Undang Nomor 10 Tahun 1998 belum spesifik sehingga belum menegaskan mengenai posisi bank syariah dan bank konvensional dalam sistem perbankan nasional. ${ }^{24}$

- Lahirnya KHES berawal dari terbitnya Undang-Undang Nomor 3 Tahun 2006 tentang Perubahan atas Undang-Undang Nomor 7 Tahun 1989 Tentang Peradilan Agama. Undang-

22 Akhyar Ari Gayo, Jurnal Rechts Vinding: Media Pembinaan Hukum Nasional, Dinamika Legislasi Hukum Islam : Analisa Atas Upaya Pembentukan Hukum Perikatan Syariah, Volume 4 No 3 (desember-2015), h.486.

23 Ridwan, Jurnal Al-Risalah: Forum kajian Hukum dan Sosial Kemasyarakatan, Legislasi Hukum Ekonomi Syariah Dalam Bingkai Hukum Nasional Indonesia, Volume 16 No 1 (Juni-2016), h. 107.

${ }^{24}$ Neneng Nurhasanah dan Panji Adam, Hukum Perbankan Syariah: Konsep dan Regulasi, (Yogyakarta: Parama Publishing, 2012), h. 14. 
Undang ini memperluas kewenangan PA sesuai dengan perkembangan hukum dan kebutuhan umat Islam Indonesia saat ini, dengan perluasaan wewenang tersebut kini PA tidak hanya berwenang menyelesaikan sengketa dibidang perkawinan, waris, wasiat, hibah, wakaf, dan sadaqah saja, melainkan menangani kasus dalam pengankatan anak, menyelesaikan dalam sengketa zakat, infaq, serta sengketa hak milik dan sengketa keperdataan lainnya antara sesama muslim , dan ekonomi syariah. ${ }^{25}$

- Diundangkannya Undang-Undang Nomor 41 Tahun 2004 tentang Wakaf untuk melengkapi Undang-Undang tersebut, pemerintah telah menetapkan PP Nomor 42 Tahun 2006 tentang Pelaksanaan Undang-Undang Nomor 41 Tahun 2004 ditambah dengan Keputusan Menteri Nomor 4 Tahun 2009 tentang administrasi wakaf uang. Hal ini menunjukkan politik ekonomi Islam yang diperagakan pemerintah RI dalam ranah keuangan publik Islam secara legal formal. $^{26}$

- Undang-Undang Nomor 38 Tahun 1999 tentang Pengelolaan Zakat, sebenarnya regulasi mengenai zakat di Indonesia sudah dimulai sejak tahun 1968 melalui Peraturan Menteri Agama Nomor 4 Tahun 1968. Politik hukum pemerintah tentang zakat mencapai titik terang ketika terbitnya Undang-Undang Nomor 38 Tahun 1999 tentang pengelolaan zakat yang dalam hal ini menghasilkan Badan Amil Zakat Nasional (BAZNAS) melalui keputusan Presiden Nomor 8 Tahun 2001. Selanjutnya Undang-Undang tentang Pengelolaan Zakat dirubah menjadi UndangUndang Nomor 38 Tahun 2011. ${ }^{27}$

\section{Politik Hukum Pembentukan Legislasi Ekonomi Syariah Di Indonesia}

Studi politik hukum Islam di Indonesia dalam dewasa ini banyak mendiskusikan terkait kepentingan masyarakat mayoritas yang notabenenya adalah masyarakat muslim. Dalam artian bahwa politik hukum Islam subtansinya menyangkut urgensi hukum pada sebagian besar rakyat Indonesia. ${ }^{28}$ dalam hal ini apabila merujuk dalam gagasan Mahfud MD dijelaskan bahwa politik hukum sebagai garis kebijakan resmi dalam suatu negara yang akan diberlakukan baik dalam pembuatan hukum baru maupun penggantian hukum lama, dalam rangka mencapai tujuan negara dengan dasar tidak bertentangan dengan dasar negara Pancasila dan Konstusi negara UUD NRI 1945.

\footnotetext{
${ }^{25}$ Ramdlon Naning, Jurnal Varia Advokat, Penyelesaian Sengketa Dalam Islam, Volume 6 (2008), h. 29

${ }^{26}$ Ridwan, Legislasi Hukum..., h. 107.

${ }^{27}$ Mustafa Khamal Rokan, Politik Hukum..., h. 8.

${ }^{28}$ Abdul Halim, Politik Hukum Islam di Indonesia, (Jakarta: Ciputat Press, 2005), h. 4.
} 
Dalam Faruqi’s Law Dictionary kataa legislasi yasyra’u, yakni mengundangkan, disebut juga qanunan, taqninan, atau tasyri'an. ${ }^{29}$ Istilah dalam kamus edisi lengkap bahasa Belanda "wet Geving" yaitu perundang-undangan. ${ }^{30}$ Namun definisi umum yang terlihat di Indonesia mengenai legislasi adalah suatu proses di lembaga legislatif, yakni pembuatan peraturan perundang-undangan. Berkaitan dengan materi hukum Islam dal proses legislasi melalui mekanisme positivisasi. Dalam positivisasi ini dijelaskan proses dalam pembangunan hukum nasional dengan dua bentuk: (1) hukum Islam tidak dapat diberlakukan dalam skala nasional karena kondisi pluralitas bangsa Indonesia, namun hukum Islam dapat menjadi sumber nilai dalam penyusunan hukum nasional. (2) hukum Islam dapat menjadi hukum positif berlaku bagi semua warga melalui proses legislasi yang sah seperti bidang ekonomi syariah. ${ }^{31}$

Sistem hukum di Indonesia mengikuti tradisi civil law yang ciri utamanya adalah peraturtan perundang-undangan yang terkodifikasi. Sementara itu hukum Islam Islam walupun memiliki sumber-sumber tertulis pada Al-Qur'an dan As-Sunnah dan pendapat para fuqaha pada umumnya tidak terkodifikasi dalam bentuk buku perundang-undangan yang mudah dirujuk. Oleh karen hukum Islam di Indonesia sama halnya juga hukum adat, sering dilihat sebagai hukum tidak tertulis dalam bentuk perundang-undangan.

Berdasarkan uraian diatas, maka umat Islam yang menghendaki permberlakuan ekonomi syariah sebagai hukum positif tentu harus mengupayakan politik hukum melalui legislasi dengan menyusun draf Rancangan Undang-Undang (RUU) yang diajukan kepada Badan Legislatif (DPR) untuk mendapatkan persetujuan. ${ }^{32}$ Berkenaan dengan proses legislasi dapat dikatakan mencakup kegiatan mengkaji, merancang, membahas dan mengesahkan undang-undang, serta pengajuan ini bisa melalui presiden atau inisiatif DPR.

Selanjutnya program legislasi nasional biasanya disebut dengan Proglegnas dalam konteks kebijakan politik hukum perundang-undangan di Indonesia dimaksudkan untuk merencanakan program pembentukan undang-undang yang dianggap prioritas nasional untuk mengatasi aneka permasalahan hukum dimasyarakat. Prolegnas dilaksanakan selama lima tahun jabatan DPR dan Presiden sebagai dua institusi yang memiliki kewenangan mengusulkan

${ }^{29}$ Harith Suleiman Faruqi, Faruqi’s Law Dictionary English-Arabic, Edisi IV, (Beirut: Librarie Duliban, 1991), h. 415 .

${ }^{30}$ Yan Pramadya Puspa, Kamus Hukum Edisi Lengkap Bahasa Belanda, Indonesia, Inggris, (Jakarta: Aneka Semarang, 1997), h. 916.

${ }^{31}$ Panji Adam, Tahkim: Jurnal Peradaban dan Hukum Islam, Legislasi Hukum Ekonomi Syariah: Studi Tentang Produk Regulasi Hukum Ekonomi Syariah di Indonesia, Volume 1 No 2 (Oktober-2019), h. 75.

${ }^{32}$ Illy Yanti, Formalisasi Hukum..., h. 15. 
peraturan perundang-undangan sebagaaimana dimaksud dalam ketentuan Pasal 20 UUD 1945 pasca amandemen. Prolegnas merupakaan instrument perencanaan pembentukan peraturan perundang-undangan yang diharapkan melalui prolegnas ini upaya dalam pembentukan materi hukum dapaat berjalan secara lebih terpadu dan sistematis.

Dalam konteksn ini jika merujuk pada teori perundang-undangan, Hierarki peraturan perundang-undangan menurut Han Kelsen hukum adalah suatu hierarki mengenai hubungan normatif, yang terdiri atas norma dasar, norma umum, dan norma konkrit. ${ }^{33}$ Norma dasar terdapat dalam konstitusi, norma umum terdapat dalam undang-undang, dan norma konkrit terdapat dalam putusan pengadilan/pejabat negara. afiliasi antar norma dikatakan bahwa norma yang lebih tinggi dengan norma yang lebih rendah merupakan hubungan hierarki norma, sehingga dapat disimpulkan bahwa norma yang lebih rendah derajatnya tidak dibenarkan bertentangan dengan norma diatasnya. ${ }^{34}$

Dalam dewasa ini mentransformasikan ekonomi syariah dalam bentuk Peraturan Perundang-Undangan yang baik sekurang-kurangnya harus memenuhi empat landasan, yaitu: landasan filosofis, landasan sosiologis, landasan yuridis, dan landasan politis.

- Landasan filosofis, berisi nilai-nilai moral atau etika dari bangsa tersebut, moral dan etika pada dasarnya berisi nilai-nilai baik dan tidak baik, sedangkan nilai baikmerupakan pandangan dan cita-cita yang dijunjung tinggiyang didalamnya ada nilai kebenaran, keadilan dan kesusilaan serta sebagai nilai lainnya yang dianggap baik.

- Landasan sosiologis, ketentuan-ketentuannya harus sesuai dengan keyakinan umum atau kesadaran hukum masyarakat. Hal ini menjadi penting jika nantinya undang-undang yang dibuat nanti ditaati oleh masyarakat. Hukum yang dibuat harus sesuai dengan hukum yang hidup (the living law) dalam masyarakat, namun produk perundang-undangan tidak sekedar meredam keadaan seketika, sebab jika keadaan masyarakat berubah, nilai-nilai akan berubah, kecenderungan dan harapan masyarakat harus dapat diprediksi dan terakumulasi dalam peraturan perundang-undangan yang berorientasi pada hukum masa akaan datang.

${ }^{33}$ Agus Riwanto, Jurnal Cita Hukum Fakultas Syariah dan Hukum UIN Jakarta, Strategi Politik Hukum Meningkatkan Kualitas Kinerja DPR RI Dalam Produktivitas Legislasi Nasional, Pengajar Hukum Tata Negara Fakultas Hukum dan Program Pascasarjana Ilmu Hukum Universitas Sebelas Maret (UNS) Surakarta, Volume 4 Nomor 2 (Desember-2016), h. 269.

${ }^{34}$ Jimlly Asshidiqie, Perihal Undang-Undang di Indonesia, (Jakarta: Mahkamah Konstitusi RI, Sekretariat Jendral dan Kepaniteraan, 2006), h. 38. 
- Landasan yuridis, merupakan landasan hukum yang yang menjadi dasar kewenangan. ${ }^{35}$ Dasar hukum kewenangan membentuk peraturan perundang-undangan sangat diperlukan, tanpa disebutkan dalam peraturan perundang-undangan seorang pejaabat atau suatu badan adalah tidak berwenang mengeluarkan peraturan.

- Landasan politis, merupakan garis kebijakan politik yang menjadi dasar selanjutnya bagi kebijaksanaan dan pengarahan atas terlaksananya pemerintahan negara. konklusinya adalah sejalan dalam program legislasi nasional. ${ }^{36}$

Dalam memperkuat proses legislasi ekonomi syariah kedalam jalur legislasi, setidaknya perlu agar memperhatikan tiga hal yaitu substansi, bentuk dan proses. Dalam hal substansi, diperlukan doktrin-doktrin yang ada dalam kitab fikih, ijtihad, dan fatwa para ulama, serta putusan hakim dalam bentuk yurisprudensi yang sudah terakomodir dalam peraturan perundangundangan, menjadi acuan yang tak terabaikan. Dalam bentuk yang harus diperhatikan yakni jangkauan berlakunya disesuaikan dengan tingkat hierarki perundang-undangan di Indonesia. sedangkan dalam hal proses tergantung dalam hal yang dipilih, karena legislasi ekonomi syariah prosesnya akan lebih sulit dari pada bentuk peraturan pemerintah dan aturan-aturan dibawahnya.

Secara elektis para pembentuk aturan hukum di Indonesia memilih dan menetapkan materi hukum dari macam-macam sumber hukum Agama, Adat, Hukum Barat, dan lain-lain. ${ }^{37}$ Mereka memilih materi hukumdari berbagai sumber hukum dari berbagai sumber hukum tersebut yang dipandang paling tepatuntuk diterapkan di Indonesia. dengan elektisme ini, hukumIslam menjadi sumber utama dalam pengambilan materi hukum, baik yang kemudian menjadi bagian dari substansi aturan hukun yang dielaborasi dengan nama syariah.

Pijakan arah politik hukum bidang ekonomi syariah di Indonesia baru tampak dalam tahapan legislasi Undang-Undang Nomor 7 tahun 1992 tentang Perbankan, yang memungkinkan beroperasinya bank dengan sistem bagi hasil. Undang-Undang ini kemudian dirubah dengan Undang-Undang Nomor 10 Tahun 1998 tentang Perubahan atas Undang-Undang Nomor 7 tahun 1992 tentang perbankan, yang secara eksplisit menyebutkan istilah "bank berdasarkan prinsip syariah”. Lahirnya Undang-Undang tersebut menjadi moment penting bagi dimulainya gerakan ekonomi syariah di Indonesia. setelah itu gerakan ekonomi syariah terus diagungkan dan diperjuangkan oleh aktivis ekonomi syariah, baiki para ulama, akademisi maupun praktisi yang

35 Suhartono, Menggagas Legislasi Ekonomi Syariah ke Ranah Sistem Hukum Nasional, www. Badilag. Net. Akses 9 Maret 2021.

${ }^{36}$ Illy Yanti, Formalisasi Hukum..., h. 16.

${ }^{37}$ Akhyar Ari Gayo, Dinamika Legislasi..., h. 490. 
tidak kenal lelah. Hal ini tentunya secara bertahap menjadikan hukum syariah diundangkan dalam konstitusi hukum positif dapat menjamin kepastian hukum umat Islam Indonesia. ${ }^{38}$

Dalam melihat sejauh mana jangkauan tendesius politik hukum nasional dalam kedudukan ekonomi syariah di Indonesia, perlu kita mencium melalui dua aspek, diantaranya melalui aspek kelembagaan dan aspek substansi hukum yang terdapat dalam lahirnya peraturan perundang-undangan yang ada. Dalam kajian kelembagaan politik hukum memberikan nasional memberikan pengaturan yang memiliki wewenang dalam sistem pengelolaan ekonomi syariah. Sebagai salah satu contoh, keberadaan peradilan agama sebagai institusi kekuasaan kehakiman yang diberi kewenangan untuk menyelesaikan sengketa ekonomi syariah dalam yurisdiksi absolutnya. Hal ini dapat dilihat dalam hasil produk legislasi ketentuan pasal 49 Undang-Undang Nomor 3 Tahun 2006 tentang perubahan Pertama Undang-Undang Nomor 7 Tahun 1989 tentang peradilan agama. ${ }^{39}$

Pada ranah kelembagaan pula, hadirnya Dewan Syariah Nasional (DSN) dan Badan Arbitrase Syariah (Bayarnas) asalah lompatan maju dalam politik hukum nasional. Kedua lembaga tersebut berada dibawah MUI. Dalam struktur ketatanegaraan, MUI bukanlah bukanlah bagian dari organ kekuasaan resmi negara. MUI lebih tepat jika disebut sebagai badan hukum biasa, Ia sejajar dengan berbagai organisasi keagamaan lainnya. Selanjutnya hadirnya DSN dan Bayarnas dalam struktur hukum nasional seiring dengan diberlakukannya Undang-Undang Nomor 21 Tahun 2008 tentang Perbankan Syariah, Undang-Undang tersebut menuntut hadirnya institusi penetapan legislasi dan pengawas fatwa di bidang ekonomi syariah yang dilakukan oleh DSN, serta institusi penyelesaian sengketa di luar dari pengadilan. Sebagai kelembagaan Bayarnas dimaksudkan sebagai cara penyelesaian sengketa pilihan selain ke Penegadilan Agama. $^{40}$

Dalam aspek peraturan hadirnya berbagai Undang-Undang seperti Undang-Undang Nomor 21 Tahun 2008 tentang Perbankan Syariah, Undang-Undang Nomor 19 Tahun 2008 tentang Surat Berharga Syariah Nasional, Undang-Undang Nomor 23 Tahun 2011 tentang Pengelolaan Zakat, Undang-Undang Nomor 7 Tahun 1989 sebagaimana mengalami perubahan melalui Undng-Undang Nomor 3 Tahun 2006 tentang Peradilan Agama, dan Undang-Undang Nomor 41 Tahun 2004 tentang wakaf. Namun dalam konteks laain misalnya secaraa lebih spesifik dijelaskan bahwaa Fatwa DSN MUI yang sesungguhnya bukan bagian dari produk

\footnotetext{
${ }^{38}$ Lukman Santoso, Politik Hukum..., h. 112. Lihat dalam \{Citation\}

${ }^{39}$ M. Rifqinizamy Karsayuda, Politik Hukum..., h. 45.

${ }^{40}$ Ibid, h. 45.
} 
peraturan perundang-undangan nasional kita, juga dapat dilihat sebagaai dasar hukum dan tata kelola ekonomi syariah di Indonesia, setelah dilakukan otorisasi oleh Bank Indonesia melalui Peraturan Bank Indonesia sebagaimana diatur dalam Undang-Undang Nomor 21 Tahun 2008 tentang Perbankan Syariah. ${ }^{41}$

Berdasarkan uraian panjang diatas bermula dari legislasi hingga tercapainya sebuah produk hukum bukan sesuatu pekerjaan rumah yang mudah, dari proses legislasi dalam kacamata politik hukum bahwa afiliasi terlihat sangat signifikan perubahan politik nasional terhadap pelembagaan ekonomi syariah, begitu pula suasana diparlemen partai-partai Islam bermunculan. Situasi ini memungkinkan secara politik karena beberapa faktor, anatara lain kelompok Islam banyak berada dalam lembaga legislasi, banyak partai-partai Islam, terjadi perubahan sistem politik dimasyarakat maupun elit politik, sehingga narasi-nasrasi Islam menjadi netode mendapat dukungan umat Islam, dan politik ekonomi Internasional, fenomena Bank Islam yang sudah menjadi realitas global. Dalam konteks ini yang pada akhirnya membuat pelembagaan ekonomi syariah telah menjadi suatu kebutuhan dan keharusan bagi negara untuk menjamin dan menjaga keyakinan umat Islam Indonesia, sesuai dengan Pancasila dan Undang-Undang dasar $1945 .{ }^{42}$

\section{Kesimpulan}

Politik hukum adalah legal policy atau disebut dengan garis kebijakan resmi tentang hukum yang akan diberlakukan baik dalam perihal pembuatan hukum baru atau penggantian hukum lama dalam proses mencapai tujuan negara. Politik hukum diartikan sebagai suatu kebijakan untuk melaksanakan tujuan negara khususnya dalam bidang hukum pada hukum yang akan berjalan, sedang berjalan dan telah berlaku yang dimbil melalui nilai-nilai dalam masyarakat untuk mencapai tujuan negara sebagaimana terdapat dalam UUD NRI 1945 alinea ke-4, yang memberi ketegasan dalam cita-cita yang harus dicapai oleh bangsa Indonesia melalui organisasi Negara Kesatuan Republik Indonesia.

Dalam konteks legislasi ekonomi syariah politik hukum nasional memberikan tempat sifatnya tendensi yang kuat pada proses legislasi hukum Islam, baik pada aspek kelembagaan, maupun substansi pengaturannya. Hal ini sebagai mempertegas, bahwa keberadaan umat Islam sebagai mayoritas penduduk Indonesia diberikan perlindungan hukum yang baik oleh negara. pada sisi lain, diskursus perlu tidaknya Islam diletakkan sebagai dasar negara, sekaligus

${ }^{41}$ Ibid, h. 45

42 Fauzan Ali Rasyid, Ijtihad: Jurnal Wacana Hukum Islam dan Kemanusiaan, Konfigurasi Politik Hukum Ekonomi Syariah di Indonesia, Volume 16 No 2 (Desember-2016), h. 313. 
menjadikan Islam sebagai hukum Positif, secara substansial bahwasanya hukum Islam dapat dijadikan bagian dari hukum positif nasional kita.

\section{DAFTAR PUSTAKA}

Adam, Panji. Legislasi Hukum Ekonomi Syariah: Studi Tentang Produk Regulasi Hukum Ekonomi Syariah di Indonesia. Tahkim: Jurnal Peradaban dan Hukum Islam. Volume 1 No 2, Oktober-2019.

Hasan, Ahmadi. Sejarah legislasi hukum ekonomi syariah di Indonesia. LKiS, 2017.

Asshidiqie, Jimlly. Perihal Undang-Undang di Indonesia. Jakarta: Mahkamah Konstitusi RI, Sekretariat Jendral dan Kepaniteraan, 2006.

Faruqi, Harith Suleiman. Faruqi's Law Dictionary English-Arabic, Edisi IV. Beirut: Librarie Duliban, 1991.

Fasiha. Ekonomi dan Bisnis Islam: Seri Konsep dan Aplikasi Ekonomi dan Bisnis Islam. Jakarta: PT Raja Grafindo Persada, 2016.

Gayo, Akhyar Ari. Dinamika Legislasi Hukum Islam : Analisa Atas Upaya Pembentukan Hukum Perikatan Syariah. Jurnal Rechts Vinding: Media Pembinaan Hukum Nasional. Volume 4 No 3, Desember-2015.

Halim, Abdul. Politik Hukum Islam di Indonesia. Jakarta: Ciputat Press, 2005.

Irawan, Mul. Politik Hukum Ekonomi Syariah Dalam Perkembangan Lembaga Keuangan Syariah Di Indonesia. Jurnal Media Hukum. Volume 25 No 1, Juni-2018.

Karsayuda, M. Rifqinizamy. Politik Hukum Nasional Legislasi Hukum Ekonomi Syariah. Jurnal Syariah dan Hukum:de Jure. Volume 7 No. 1, Juni-2015.

MD, Moh. Mahfud. Politik Hukum di Indonesia, Cet Ke-3. Jakarta: Rajawali Press, 2010.

Naning, Ramdlon. Penyelesaian Sengketa Dalam Islam. Jurnal Varia Advokat. Volume 6, 2008.

Nurhasanah, Neneng dan Panji Adam. Hukum Perbankan Syariah: Konsep dan Regulasi. Yogyakarta: Parama Publishing, 2012.

Puspa, Yan Pramadya. Kamus Hukum Edisi Lengkap Bahasa Belanda, Indonesia, Inggris. Jakarta: Aneka Semarang, 1997.

Rahardjo, Satjipto. Membangun dan Merombak Hukum Indonesia Sebuah Pendekatan Lintas Disiplin. Yogyakarta: Genta Publishing, 2009. 
Rasyid, Fauzan Ali. Konfigurasi Politik Hukum Ekonomi Syariah di Indonesia. Ijtihad: Jurnal Wacana Hukum Islam dan Kemanusiaan. Volume 16 No 2, Desember-2016.

Ridwan, Legislasi Hukum Ekonomi Syariah Dalam Bingkai Hukum Nasional Indonesia. Jurnal Al-Risalah: Forum kajian Hukum dan Sosial Kemasyarakatan. Volume 16 No 1, Juni2016.

Riwanto, Agus. Strategi Politik Hukum Meningkatkan Kualitas Kinerja DPR RI Dalam Produktivitas Legislasi Nasional. Jurnal Cita Hukum Fakultas Syariah dan Hukum UIN Jakarta, Pengajar Hukum Tata Negara Fakultas Hukum dan Program Pascasarjana Ilmu Hukum Universitas Sebelas Maret (UNS) Surakarta. Volume 4 Nomor 2, Desember2016.

Rokan, Mustafa Khamal. Politik Hukum Ekonomi Syariah di Indonesia, 2015.

Santoso, Lukman. Politik Hukum Ekonomi Syariah. Jurnal Sosio-Religia. Volume 10 No. 2, Mei-2012.

Suhartono. Menggagas Legislasi Ekonomi Syariah ke Ranah Sistem Hukum Nasional. www. Badilag. Net. Akses, 9 Maret 2021.

Suma, Muhammad Amin. Himpunan Undang-Undang Perdata Islam dan Peraturan Pelaksana Lainnya Di Negara Hukum Indonesia. Jakarta: Raja Grafindo Persada, 2004.

Syaukani, Imam dan A. Ahsin Thohari. Dasar-Dasar Politik hukum, Cet Ke-8. Jakarta: Rajawali Press 2012.

Yanti, Illy. Formalisasi Hukum Ekonomi Islam Di Indonesia (Studi Tentang Pemberlakuan Hukum Ekonomi Islam Pasca Lahirnya UU No. 3 Tahun 2006). Jurnal: Al-Risalah. Volume 13 No 2, Desember-2013. 